\title{
SPATIAL ECONOMETRIC ANALYSIS OF BETA-CONVERGENCE ACROSS ITALIAN REGIONS USING RECONSTRUCTED HISTORICAL DATA, 1891-2016
}

\author{
[Prostorová ekonometrická analýza beta-konvergence italských regionů s \\ použitím rekonstruovaných historických dat, 1891-2016]
}

\author{
Jan Belardi ${ }^{1}$ \\ ${ }^{1}$ VŠB - Technical University of Ostrava, Faculty of Economics, Sokolská tř. 33, 70200 Ostrava \\ Email: jan.belardi@seznam.cz.
}

\begin{abstract}
The convergence of economic level across regions is nowadays discussed especially in association with the efficiency of the EU Cohesion policy. This is the reason why many researchers investigate economic convergence only in a short term, during the last few decades. It is also caused by the lack of historical statistical data for regional levels. We solved this problem atypically by using reconstructed historical regional data that allow us to investigate the convergence in a long term. In this paper, we focus on Beta-convergence of Italian regions using real per capita GDP. The time series consists of reconstructed historical regional data for the period 1891-2009 and regional data from ISTAT for the period 1995-2016. The aim of this paper is to evaluate the process of Beta-convergence across Italian regions in the period 1891-2016 through spatial econometric analysis considering different political background. We used cross-sectional analysis which was extended by the spatial lag model through spatial weights matrix. The whole period was divided into shorter time spans according to the important milestones in the Italian history. We found out that there were times of regional convergence, divergence and stagnation. There are two most remarkable periods: the divergence era which started at the beginning of WWI and continued through interwar period until the end of WWII and the convergence era during miracolo economico italiano in the 1950s and 1960s.
\end{abstract}

Keywords: Beta-convergence, cross-sectional analysis, Italian regions, spatial econometrics, spatial lag model.

JEL classification: C21, N90, O47, R11, R15

Received: 5.10.2018; Reviewed: 22.11.2018; 26.11.2018; Accepted: 6.3.2019

\section{Introduction}

The regional convergence is not outmoded issue. Even though the main goal of the EU Cohesion policy is reduction of regional disparities, the differences in economic level across European regions are persisting and significant. Moreover, we observe that considerable regional differences within countries might lead to demands for political independence in economically powerful regions. Nowadays, in the recovery from the recession which halted the long-term reduction in disparities in per capita GDP, the differences have started to shrink again (European Commission 2017). Nevertheless, Iammarino, Rodríguez-Pose and Storper (2017) point out that regional economic divergence has become a threat to Europe in terms of economic progress, social cohesion and political stability.

There are some arising questions. How the long-term convergence process looks like and is the stagnation of convergence process unusual? We decided to clarify these questions on the case of Italy, where the regional disparities are notorious and extensive. Our investigation is based on spatial econometric analysis of Beta-convergence in the long term using real per capita GDP. We analyse reconstructed historical data to solve the problem of data limitations. 
The aim of this paper is to evaluate the process of Beta-convergence across Italian regions in the period 1891-2016 through spatial econometric analysis considering different political background. Spatial econometric analysis is based on spatially extended cross-sectional model. The spatial weights matrix is incorporated into the model to catch the spillover effects across regions. To achieve the aim of the investigation, we use software - QGIS 3.2 Bonn Geographic Information System (QGIS Development Team 2018) to create modified shapefile of aggregate administrative structure of Italy (see section 2.1 and Appendix) which is then used for spatial econometric analysis in Stata 15 (StataCorp 2017).

The paper is organized as follows. In the section 1, we briefly review the literature related to the concept of Beta-convergence and to the spatial econometric approach. Section 2 is dedicated to data and methodology of our investigation. In the subsection related to the methodology we present a cross-sectional model of Beta-convergence which is afterwards extended by the spatial lag model. Section 3 contains results of econometric analysis and discussion. Finally, last section points out the most important findings of our research.

\section{Literature review}

In this paper, we investigate the real convergence process across Italian regions on the basis of Beta-convergence concept. This approach extends the neoclassical Solow-Swan exogenous growth model (see Solow 1956 and Swan 1956). The model assumes some conditions: a closed economy, exogenous saving rates and a production function based on decreasing productivity of capital and constant returns to scale (Arbia and Basile 2005). Le Gallo, Ertur and Baumon (2003, p. 102) state that: "The prediction of the model (Solow 1956) is that the growth rate of an economy will be positively related to the distance that separates it from its own steady state. If economies have different steady states, this concept is therefore compatible with a persistent high degree of inequality among economies." Economies converge to the same steady state when these economies are assumed to be structurally similar (Le Gallo, Ertur and Baumon 2003). According to Barro and Sala-i-Martin (2004) regions within one country tend to converge to similar steady states due to smaller differences in technology, preferences or institutions across regions than those across countries. The process when the economies (which differ only by their initial conditions) converge to the same steady state is defined as an unconditional or absolute Beta-convergence. The absolute Beta-convergence occurs when poor economies grow faster than rich ones and eventually catch them up in the long term (Sala-iMartin 1996; Le Gallo, Ertur and Baumon 2003).

Based on this theoretical framework Barro and Sala-i-Martin $(1990,1992,2004)$ formulated widely used Beta-convergence model which assumes a negative relationship between the growth of real per capita GDP over a definite time span and the initial economic level measured by the real per capita GDP (Piras and Arbia 2007). All equations related to this concept of convergence are presented in subsection 2.2.

As mentioned above, a closed economy is one of the neoclassical growth model conditions. Arbia, Basile and Piras (2005) or Arbia and Basile (2005) notice that this condition is too strong for regions within a country. It is caused by the fact that the barriers to trade and to factor flows are considerably lower across regions within one country than across different countries. Thus, according to Arbia, Basile and Piras (2005) we must consider the role of factor mobility, trade relations, technological diffusion or knowledge spillover across regions in our analysis. This phenomenon is known as spatial dependence which often arises in spatial data samples (observations that are associated with points or regions). Spatial dependence occurs when values from one location depend on the values of neighboring observations at nearby locations 
(LeSage and Pace 2009). In other words, spatial dependence occurs when observations are geographically correlated. This can be caused by processes across different areas such as trade, labour force and capital mobility, technology and knowledge diffusion or transportation (Le Gallo, Ertur and Baumon 2003).

There is a lot of empirical literature related to economic growth and convergence that stresses the importance of spatial dependencies (see e.g. Abreu, De Groot and Florax 2005). Le Gallo, Ertur and Baumon (2003) point out that space and location is very important in the analysis of convergence and growth processes and should not be neglected. According to the research related to regional per capita income distribution, Quah (1995, p. 7-8) noticed: “[...] physical location and geographical spillover matter more than do macro factors. [...] the results highlight the importance of spatial and national spillovers in understanding regional income distribution dynamics."

Arbia, Basile and Piras (2005) notice that a direct way to control for spatial interaction effects on convergence is to include interregional flows of labour, capital and technology in the growth regression model. However, this direct approach is limited by data availability. Fortunately, there is also an indirect way to control for the effects of interregional flows on growth and convergence - spatial dependence models. There are two models which has been originally the central focus of spatial econometrics: the spatial lag model (or spatial autoregressive model, SAR) and the spatial error model (Elhorst 2014). In this paper, we will take spatial dependence into account through the spatial lag model. This model contains a spatial lag operator as a new independent variable which consists of a weighted average of the growth rates at neighboring locations (Anselin and Bera 1998). This concept is based on an exogenously determined spatial weights matrix W. In accordance with Le Gallo, Ertur and Baumon (2003) we assume that our spatial lag model captures the net effects of the omitted economic factors. All the essentials of this spatial lag model are defined in the subsection 2.2.

\section{Data and methodology}

This section is dedicated to data and methodology used in our paper. In the subsection 2.1 we describe the data. Our investigation is based on reconstructed historical regional time series and regional data from ISTAT. Subsection 2.2 related to methodology contains models for econometric analysis of Beta-convergence across Italian regions.

\subsection{Data}

The econometric analysis of Beta-convergence across regions requires data on regional economic level (per capita GDP) for sufficiently long period. However, Le Gallo, Ertur and Baumon (2003) point out that in the European regional context there is problem of data limitations. Many researchers use EUROSTAT database which offers harmonised regional statistics by NUTS classification. However, these time series beginning in 2000 are somewhat short. Regional time series from The Italian National Institute of Statistics (ISTAT) are available only from 1995. We solved this problem atypically using reconstructed historical dataset presented by Daniele and Malanima (2011). This dataset contains annual data on real per capita GDP over the period 1891-2009 for Italy and its regions. During this long period the borders have changed, however all reconstructed time series refer to Italy and Italian regions in the actual shape. Moreover, several of 20 Italian regions, which correspond to NUTS 2, were aggregated by Daniele and Malanima (2011) to bigger ones (Piemonte includes Valle d'Aosta; Veneto includes Trentino-Alto Adige and Friuli-Venezia Giulia; and Abruzzo includes Molise). The differences between Italian official administrative structure (20 regions) and aggregate 
structure (16 regions) is depicted in Appendix. We used QGIS Geographic Information System (QGIS Development Team, 2018) to modify the official shapefile from ISTAT (2011).

Reconstructed time series of regional per capita GDP over the period 1891-2009 in euros (constant 2010 prices) are depicted in Figure 1. Considering this figure, it is difficult to draw some general conclusion about the convergence process across 16 Italian regions.

Figure 1: Regional per capita GDP (1891-2009, constant 2010 prices, $€$ )

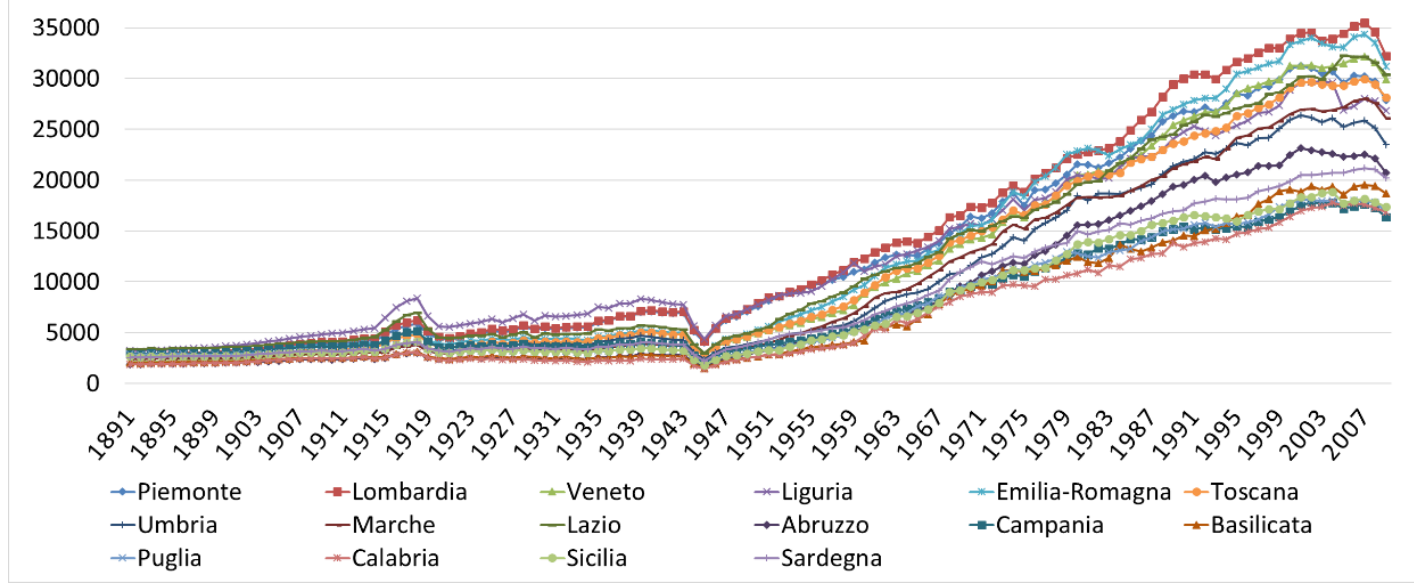

Source: Own elaboration based on Daniele and Malanima (2011)

Figure 2 illustrates recalculation based on dividing regional per capita GDP by national average. This modification is useful for the preliminary appraisal of the convergence process. We can now suppose that Italian regions probably experienced divergence (from WWI to the end of 1940s) and convergence during 1950s and 1960s.

Figure 2: Regional per capita GDP $(1891-2009$, Italy = 1)

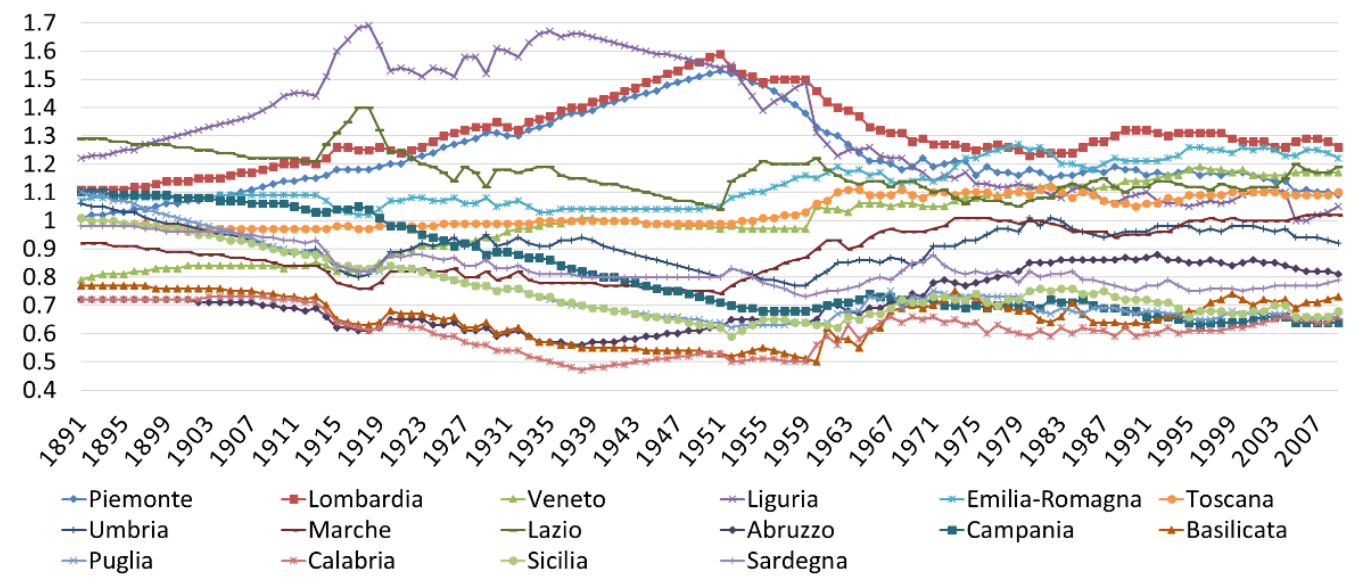

Source: Daniele and Malanima (2011), own elaboration

As mentioned above, the historical reconstructed data are available until 2009. Thus, we prolong our time series to the present with regional data from ISTAT (2018a). However, we have to recalculate per capita GDP for three aggregate regions at first. ${ }^{1}$ Figure 3 depicts

1 We used average annual population (calculated from population at the beginning and at the end of year from ISTAT, 2018b) to multiply per capita GDP of involved regions. The absolute regional GDP was the result. Then we added these absolute values of regions that make up aggregate region. Finally, the total sum was divided by average annual population of aggregate region to obtain per capita GDP. 
resulting time series of regional per capita GDP in two ways: in euros (constant 2010 prices) and in recalculation based on dividing regional per capita GDP by national average. There are no significant trends over observed period.

Figure 3: Regional per capita GDP, 1995-2016

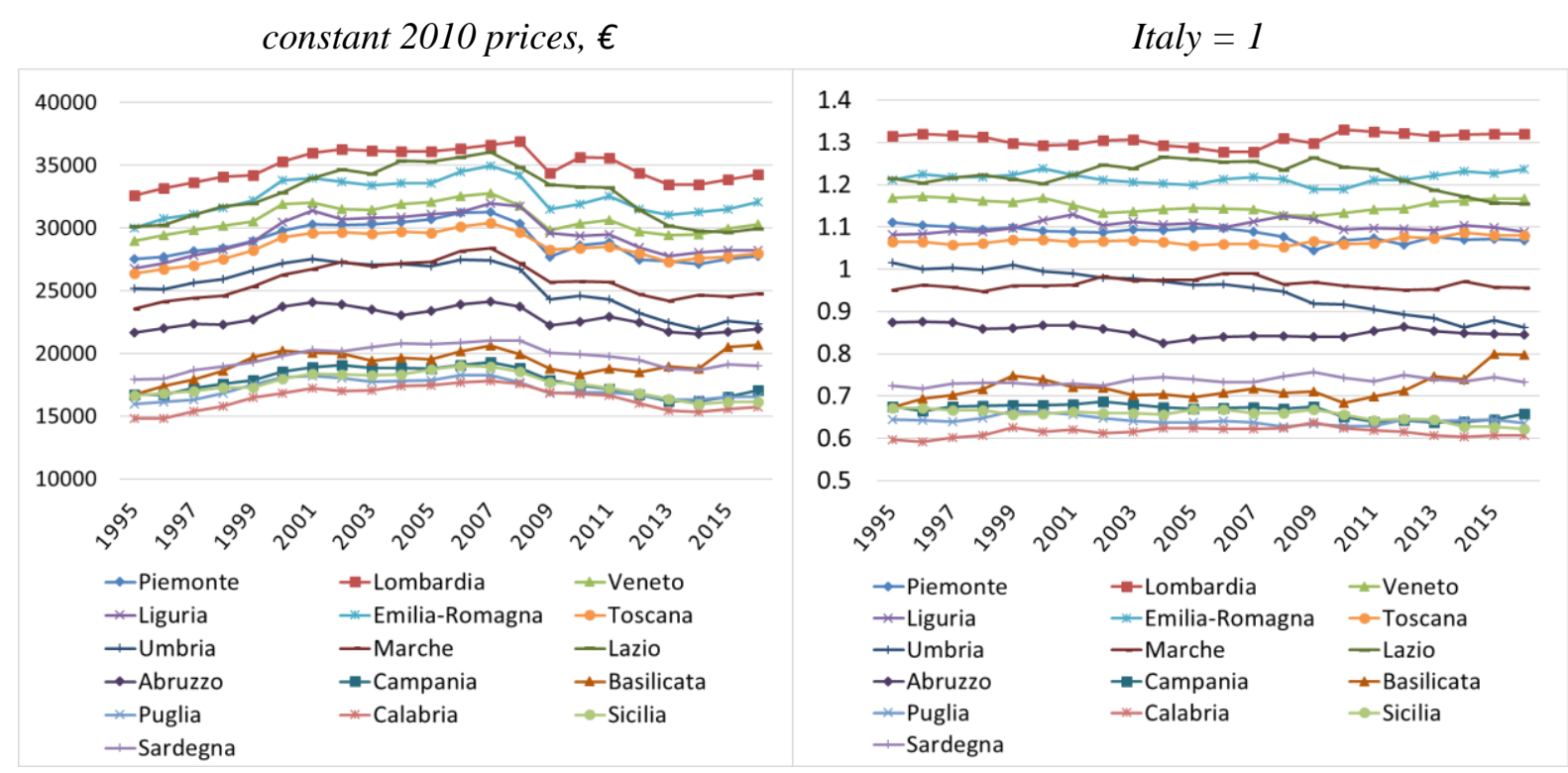

Source: Own calculations based on data from ISTAT (2018a, 2018b)

We divided the whole observed period into four shorter time spans according to the political setup and important milestones in the Italian history. The first period (1891-1913) is the democratic pre-war era. The second one (1913-1945) includes World War I, Mussolini's fascist regime and World War II. The third historical period (1946-1994) starts in 1946 when Italy became a republic. This post-war period is known as the so called Italian First Republic. The typical feature of the political system of the First Republic was fragmented party system and coalition governments always led by the Christian Democracy. This political system came to end in 1994 after extensive corruption scandals across governing class (see e.g. Belardi 2018). The last period (1995-2016) records the political success of Silvio Berlusconi, adoption of euro and the recent development until 2016.

\subsection{Methodology}

This section describes the methodology of our analysis. We use cross-sectional model of Betaconvergence to investigate the convergence process across Italian regions. This model is then extended by the spatial lag model to consider spatial interactions across regions.

\section{Cross-sectional analysis}

According to the approach presented by Barro and Sala-i-Martin (2004) we will investigate the process of Beta-convergence across Italian regions through cross-sectional analysis. We use data on regional real per capita GDP, $y_{i, t}$, where the subscript $t$ denotes the year and the subscript $i$ denotes the economy (region). The original Beta-convergence model is depicted in equation (1) which relates the average growth rate of real per capita GDP over the interval from $t_{0}$ to $t_{0}+T,\left(\frac{1}{T} \cdot \ln \left[\frac{y_{i, t_{0}+T}}{y_{i, t_{0}}}\right]\right)$, to the initial level of per capita GDP at time $t_{0},\left(\ln y_{i, t_{0}}\right)$ : 


$$
\frac{1}{T} \cdot \ln \left[\frac{y_{i, t_{0}+T}}{y_{i, t_{0}}}\right]=x-\left[\frac{1-e^{-\lambda \cdot T}}{T}\right] \cdot \ln y_{i, t_{0}}+\left[\frac{1-e^{-\lambda \cdot T}}{T}\right] \cdot \ln \hat{y}_{i}^{*}+\varepsilon_{i, t_{0}, t_{0}+T}
$$

Effect of the error terms is represented by $\varepsilon_{i, t}$ between dates $t_{0}$ and $t_{0}+T ; \hat{y}_{i}^{*}$ is the steadystate level of per capita GDP; and $x$ is the rate of technological progress which is assumed to be the same for all economies (regions in our case). According to Barro and Sala-i-Martin (2004) the coefficient on initial per capita GDP $\left[\frac{1-e^{-\lambda \cdot T}}{T}\right]$ in equation (1) declines with the length of the interval, $T$, for a given $\lambda$, because the growth rate declines as per capita GDP increases (if $y_{i, t_{0}}<\hat{y}_{i}^{*}$ ). Parameter $\lambda$ is speed of convergence which measures how fast economies converge towards the steady state. Equation (1) assumes that the average growth rate of economy (region) $i$ depends on its initial level of per capita GDP, $y_{i, t_{0}}$, but it also depends on the steady-state level of per capita GDP. This is an example of the concept of conditional convergence because the equation (1) includes steady state as an explanatory variable (Barro and Sala-i-Martin 2004; Arbia, Basile and Piras 2005).

In this paper we investigate Beta-convergence across regions within one country - Italy. As mentioned above in section 1, regions within one country tend to converge to similar steady states. It is caused by smaller differences in technology, preferences and institutions across regions than those across countries (Barro and Sala-i-Martin 2004). "Furthermore, the regions share a common central government and therefore have similar institutional setups and legal systems. This relative homogeneity means that regions are more likely to converge to similar steady states. Hence, absolute convergence is more likely to apply across regions within countries than across countries. " Barro and Sala-i-Martin (2004, p. 461). Thus, we assume that all Italian regions have a common steady state. Barro and Sala-i-Martin (2004) state that if all economies have the same steady state $\left(\hat{y}_{i}^{*}=\hat{y}_{j}^{*}\right.$ for all $i$ and $\left.j\right)$, then the term $\left[\frac{1-e^{-\lambda \cdot T}}{T}\right] \cdot \ln \hat{y}_{i}^{*}$ is included in the constant term $\alpha$. In view of that fact Barro and Sala-i-Martin $(1990,1992,2004)$ presented new equation (2):

$$
\frac{1}{T} \cdot \ln \left[\frac{y_{i, t_{0}+T}}{y_{i, t_{0}}}\right]=\alpha-\left[\frac{1-e^{-\lambda \cdot T}}{T}\right] \cdot \ln y_{i, t_{0}}+\varepsilon_{i, t_{0}, t_{0}+T}
$$

Equation (2) can be estimated directly through non-linear least squares or by re-parametrizing the statistical model and estimating by ordinary least squares (OLS) (Arbia, Basile and Piras 2005; Arbia and Basile 2005). We re-parametrize the model through following substitution:

$$
\beta=-\frac{1-e^{-\lambda \cdot T}}{T}
$$

After substitution (3) we reformulate the equation (2):

$$
\frac{1}{T} \cdot \ln \left[\frac{y_{i, t_{0}+T}}{y_{i, t_{0}}}\right]=\alpha+\beta \cdot \ln y_{i, t_{0}}+\varepsilon_{i, t_{0}, t_{0}+T}
$$

Equation (4) representing the model of absolute Beta-convergence can be estimated by OLS. If the estimate of the coefficient $\beta$ is negative and statistically significant we confirm the absolute convergence. It means that poor regions tend to grow faster than rich regions and that they all converge to the same steady-state level of real per capita GDP (Barro and Sala-i-Martin 2004; Arbia, Basile and Piras 2005; Arbia and Basile 2005). 
As mentioned above, the parameter $\lambda$ from equations (1-3) is speed of convergence, which is interpreted as the annual rate of convergence. It measures how fast economies converge towards the steady state. Another measure of convergence process is half-life, which is defined as time necessary for economies to fill half of the gap from their steady states (Arbia, Basile and Piras 2005). Speed of convergence $\lambda$ is calculated through the following formula (5) which is derived from the substitution (3). Coefficient $\beta$ is estimated from the equation 4.

$$
\lambda=-\frac{\ln (1+T \cdot \beta)}{T}
$$

Arbia and Baltagi (2010) presented the formula ${ }^{2}$ (6) which helps us to calculate the half-life $\tau$ :

$$
\tau=\frac{\ln (2)}{\lambda}
$$

\section{Spatial lag model}

In this subsection we introduce a spatial econometric approach to Beta-convergence analysis. The spatial interaction effects across Italian regions will be included into the cross-sectional model of absolute Beta-convergence (4) in accordance with spatial econometrics methods.

The spatial dependence can be incorporated into the standard linear regression model as an additional regressor in the form of a spatially lagged dependent variable (spatial lag model), or in the error term (spatial error model) (Anselin 2001).

In this paper we use the spatial lag model also known as the spatial autoregressive (SAR) model (Elhorst 2014 or LeSage and Pace 2009) or as mixed regressive, spatial autoregressive model (Anselin and Bera 1998 or Anselin 2001). The spatial lag model contains a spatial lag operator which consists of a weighted average of the growth rates in neighboring regions. Mathematically, it is the product of a spatial weights matrix $W$ with the vector of observations of variable $y$, or $W \cdot y$ (Anselin and Bera 1998). Anselin and Bera (1998) or Anselin (2001) presented the following spatial lag operator:

$$
W \cdot y_{i}=\sum_{j=1}^{n} w_{i, j} \cdot y_{j}
$$

where $w_{i, j}$ is an element of a fixed and positive $N \times N$ spatial weights matrix $W$. This element expresses the strength of the interdependence between location $i$ (in the row of the matrix) and location $j$ (column) (Anselin, Le Gallo and Jayet 2008). According to Le Gallo, Ertur and Baumont (2003) a spatial weights matrix $W$ is the fundamental tool for modelling the spatial interdependence between regions. There are several types of spatial weights matrices: a simple binary contiguity matrix; a binary spatial weights matrix with a distance-based critical cut-off, above which spatial interactions are considered negligible or sophisticated generalized distance-based spatial weights matrices with or without a critical cut-off (Le Gallo, Ertur and Baumont 2003). We use a row-normalized simple binary contiguity matrix which is based on the common boundary criterion. The binary contiguity matrix $W$ contains nonzero elements $w_{i, j}=1$ when regions $i$ and $j$ are neighbours (share the common border), and zero elements $w_{i, j}=0$ otherwise (for further details related to spatial weights matrices see e.g. Anselin and

\footnotetext{
2 Formula 6 is derived from the equation: $e^{-\lambda \cdot \tau} \cdot\left(\hat{y}_{i}^{*}-y_{i}\right)=\frac{1}{2} \cdot\left(\hat{y}_{i}^{*}-y_{i}\right)$
} 
Bera 1998; Anselin 2001; Le Gallo, Ertur and Baumon 2003; Anselin, Le Gallo and Jayet 2008; or LeSage and Pace 2009).

We reformulated the previous cross-sectional model (4) by incorporating a spatial lag operator. Thus, new spatial lag model was formed. The equation (8) represents the spatial lag model for cross-sectional data:

$$
\frac{1}{T} \cdot \ln \left[\frac{y_{i, t_{0}+T}}{y_{i, t_{0}}}\right]=\alpha+\beta \cdot \ln y_{i, t_{0}}+\rho \sum_{j=1}^{n} w_{i, j} \cdot \frac{1}{T} \cdot \ln \left[\frac{y_{j, t_{0}+T}}{y_{j, t_{0}}}\right]+\varepsilon_{i, t_{0}, t_{0}+T}
$$

The term $\rho$ in equation (8) is the spatial autoregressive parameter which indicates the extent of interactions across regions according to the spatial pattern exogenously represented by the spatial weights matrix $W$. This model indicates how the growth rate of per capita GDP in a region is influenced by the growth rates in neighboring regions (common boundary criterion) through the parameter $\rho$ after controlling for the initial level of per capita GDP (Le Gallo, Ertur and Baumon 2003). As mentioned above, in this paper we use the row-normalized binary contiguity spatial weights matrix $W$. The model specification (8) can be interpreted from the convergence and economic geography perspective. From the convergence perspective, this spatially extended model provides information on the character of convergence process through the parameter $\beta$ and from the economic geography perspective, it helps to emphasize a spatial spillover effects (Le Gallo, Ertur and Baumon 2003).

Estimation of the cross-sectional spatial lag model (8) by OLS leads to inconsistent estimators of the regression parameters because of the spatially lagged dependent variable, which is always correlated with the error term $\varepsilon$. Thus, the cross-sectional spatial lag model has to be estimated through the maximum likelihood (ML) method which is consistent for this model (Le Gallo, Ertur and Baumon 2003; LeSage and Pace 2009). Kalejian and Prucha (1998) presented another way how to estimate cross-sectional model with spatially lagged dependent variable - the generalized spatial two-stage least squares (GS2SLS) procedure. Arbia (2014) noticed that GS2SLS is useful when the assumption of normality is not satisfied. Thus, in other words, compared to ML the GS2SLS is robust to non-normality. We will use both procedures (ML, GS2SLS) to estimate the spatial lag model of Beta-convergence in Stata 15.

\section{Results and discussion}

In this section we present and discuss the results of spatial econometric analysis of Betaconvergence across Italian regions in the period 1891-2016. As mentioned above, the whole period was divided into four shorter time spans according to the important milestones in the Italian history: 1891-1913, 1913-1945, 1946-1994, 1995-2016. We will also investigate the period 1959-1969 during the economic miracle. Two cross-sectional models will be estimated - model of absolute Beta-convergence and the spatial lag model.

At first, we estimate cross-sectional model of absolute Beta-convergence using ordinary least squares (OLS). We test the assumptions of homoskedasticity (White's test and Breusch-Pagan / Cook-Weisberg test) and normality of residuals (Skewness/Kurtosis tests and Shapiro-Wilk Normality test). The results are displayed in Table 1.

The coefficient of the initial per capita GDP level from Table 1 is significant for the periods 1913-1945, 1946-1994 and 1959-1969 (p-values are in parenthesis). The models for these periods are statistically significant (see F-test) and there are no problems related to presence of 
heteroskedasticity and non-normal distribution of OLS residuals. The coefficient of determination $\mathrm{R}^{2}$ is considerable for the period 1959-1969 (0.8705). The significant and positive $\beta$ coefficient (0.016986) for the period 1913-1945 implies divergence in regional per capita GDP level. The estimated $\beta$ coefficients for the periods 1946-1994 (-0.007997) and 1959-1969 (-0.03783) are significant and negative which confirms the presence of absolute Beta-convergence. The $\beta$ coefficients for the periods 1891-1913, 1995-2016 and 1891-2009 are insignificant and the coefficients of determination $\mathrm{R}^{2}$ are very low. Thus, the presence of Beta-convergence or divergence was not validated.

Table 1: Cross-sectional model of absolute Beta-convergence across 16 Italian regions (1891-2016); OLS estimation

\begin{tabular}{|c|c|c|c|c|c|c|}
\hline \multicolumn{7}{|c|}{ Ordinary least squares (OLS) estimation } \\
\hline & $\begin{array}{c}1891- \\
1913 \\
\end{array}$ & $\begin{array}{c}1913- \\
1945 \\
\end{array}$ & $\begin{array}{c}1946- \\
1994 \\
\end{array}$ & $\begin{array}{c}1995- \\
2016 \\
\end{array}$ & $\begin{array}{c}1959- \\
1969 \\
\end{array}$ & $\begin{array}{c}1891- \\
2009 \\
\end{array}$ \\
\hline$\alpha($ constant $)$ & $\begin{array}{c}0.011738 \\
(0.834)\end{array}$ & $\begin{array}{c}-0.150429 \\
(0.011)\end{array}$ & $\begin{array}{c}0.104473 \\
(0.000)\end{array}$ & $\begin{array}{c}0.025767 \\
(0.418)\end{array}$ & $\begin{array}{c}0.388337 \\
(0.000)\end{array}$ & $\begin{array}{c}0.054289 \\
(0.035)\end{array}$ \\
\hline$\beta$ (initial per capita GDP level) & $\begin{array}{c}0.000291 \\
(0.967)\end{array}$ & $\begin{array}{c}0.016986 \\
(0.017)\end{array}$ & $\begin{array}{c}-0.007997 \\
(0.003)\end{array}$ & $\begin{array}{c}-0.002401 \\
(0.448)\end{array}$ & $\begin{array}{c}-0.03783 \\
(0.000)\end{array}$ & $\begin{array}{c}-0.004536 \\
(0.148)\end{array}$ \\
\hline F test & $\begin{array}{c}0.00 \\
(0.9674)\end{array}$ & $\begin{array}{c}7.31 \\
(0.0171)\end{array}$ & $\begin{array}{c}13.16 \\
(0.0027)\end{array}$ & $\begin{array}{c}0.61 \\
(0.4483)\end{array}$ & $\begin{array}{c}94.15 \\
(0.0000)\end{array}$ & $\begin{array}{c}2.35 \\
(0.1480)\end{array}$ \\
\hline $\mathbf{R}^{2}$ & 0.0001 & 0.3431 & 0.4845 & 0.0417 & 0.8705 & 0.1435 \\
\hline $\begin{array}{l}\text { White's test for } \\
\text { heteroskedasticity }\end{array}$ & $\begin{array}{c}2.91 \\
(0.2338)\end{array}$ & $\begin{array}{c}1.73 \\
(0.4205)\end{array}$ & $\begin{array}{c}0.68 \\
(0.7124)\end{array}$ & $\begin{array}{c}0.98 \\
(0.6125)\end{array}$ & $\begin{array}{c}0.49 \\
(0.7818)\end{array}$ & $\begin{array}{c}1.28 \\
(0.5262)\end{array}$ \\
\hline $\begin{array}{l}\text { Breusch-Pagan / Cook- } \\
\text { Weisberg test for } \\
\text { heteroskedasticity }\end{array}$ & $\begin{array}{c}2.15 \\
(0.1428)\end{array}$ & $\begin{array}{c}0.09 \\
(0.7691)\end{array}$ & $\begin{array}{c}0.04 \\
(0.8321)\end{array}$ & $\begin{array}{c}1.08 \\
(0.2981)\end{array}$ & $\begin{array}{c}0.06 \\
(0.8039)\end{array}$ & $\begin{array}{c}0.17 \\
(0.6771)\end{array}$ \\
\hline $\begin{array}{l}\text { Skewness/Kurtosis tests for } \\
\text { Normality (residuals) }\end{array}$ & $\begin{array}{c}0.21 \\
(0.8982)\end{array}$ & $\begin{array}{c}0.50 \\
(0.7795)\end{array}$ & $\begin{array}{c}2.51 \\
(0.2847)\end{array}$ & $\begin{array}{c}4.76 \\
(0.0928)\end{array}$ & $\begin{array}{c}0.93 \\
(0.6268)\end{array}$ & $\begin{array}{c}1.56 \\
(0.4577)\end{array}$ \\
\hline $\begin{array}{l}\text { Shapiro-Wilk Normality test } \\
\text { (residuals) }\end{array}$ & $\begin{array}{c}0.96806 \\
(0.80628)\end{array}$ & $\begin{array}{c}0.97532 \\
(0.91564)\end{array}$ & $\begin{array}{c}0.93506 \\
(0.29281)\end{array}$ & $\begin{array}{c}0.90047 \\
(0.08176)\end{array}$ & $\begin{array}{c}0.96530 \\
(0.75794)\end{array}$ & $\begin{array}{c}0.94870 \\
(0.46938)\end{array}$ \\
\hline
\end{tabular}

Source: Own calculations in Stata 15 (StataCorp, 2017); p-values in parenthesis

To take the spatial dependencies in our cross-sectional model into account, the spatial lag model will be estimated. As mentioned above, the spatial lag model contains spatially lagged dependent variable and it assumes that the growth rate of per capita GDP spills over from neighboring regions. This model is estimated through two procedures - maximum likelihood (ML) and generalized spatial two-stage least squares (GS2SLS).

There are two estimated effects - direct effect (own-region) and indirect (other-region, spatial spillover) effect. The sum of these effects is the total effect (LeSage and Pace 2009; Elhorst 2014; LeSage 2014). The direct and the indirect effects do not correspond directly to the estimated parameters $(\beta$ and $\rho$ ) and thus, it is not possible to interpret estimated parameters $\beta$ as the direct effect and $\rho$ as the indirect effect. In Stata 15 we have to make additional recursive computation of these effects.

Table 2 contains the results of maximum likelihood (ML) and generalized spatial two-stage least squares (GS2SLS) estimations of the cross-sectional spatial lag model. As mentioned above, we have to focus on the direct (own-region) and the indirect (spatial spillover) effects. 
Table 2: Spatial lag model of Beta-convergence (cross-sectional) across 16 Italian regions (1891-2016); ML and GS2SLS estimation

\begin{tabular}{|c|c|c|c|c|c|c|}
\hline \multicolumn{7}{|c|}{ Maximum likelihood (ML) estimation } \\
\hline & $\begin{array}{c}1891- \\
1913\end{array}$ & $\begin{array}{c}1913- \\
1945\end{array}$ & $\begin{array}{c}1946- \\
1994\end{array}$ & $\begin{array}{c}1995- \\
2016\end{array}$ & $\begin{array}{c}1959- \\
1969\end{array}$ & $\begin{array}{c}1891- \\
2009\end{array}$ \\
\hline$\alpha($ constant $)$ & $\begin{array}{c}0.017027 \\
(0.684)\end{array}$ & $\begin{array}{c}-0.12219 \\
(0.015)\end{array}$ & $\begin{array}{c}0.104731 \\
(0.000)\end{array}$ & $\begin{array}{c}0.023765 \\
(0.438)\end{array}$ & $\begin{array}{c}0.38663 \\
(0.000)\end{array}$ & $\begin{array}{c}0.053594 \\
(0.005)\end{array}$ \\
\hline$\beta$ (initial per capita GDP) & $\begin{array}{c}-0.001054 \\
(0.844)\end{array}$ & $\begin{array}{c}0.013829 \\
(0.023)\end{array}$ & $\begin{array}{c}-0.008277 \\
(0.000)\end{array}$ & $\begin{array}{c}-0.002213 \\
(0.466)\end{array}$ & $\begin{array}{c}-0.037699 \\
(0.000)\end{array}$ & $\begin{array}{c}-0.004745 \\
(0.052)\end{array}$ \\
\hline $\begin{array}{l}\rho \text { (spatial autoregressive } \\
\text { parameter) }\end{array}$ & $\begin{array}{l}0.422129 \\
(0.006)\end{array}$ & $\begin{array}{l}0.245557 \\
(0.201)\end{array}$ & $\begin{array}{c}0.056169 \\
(0.272)\end{array}$ & $\begin{array}{c}0.053746 \\
(0.848)\end{array}$ & $\begin{array}{l}0.011716 \\
(0.853)\end{array}$ & $\begin{array}{c}0.140478 \\
(0.032)\end{array}$ \\
\hline Direct effect & $\begin{array}{c}-0.001114 \\
(0.844)\end{array}$ & $\begin{array}{c}0.014062 \\
(0.020)\end{array}$ & $\begin{array}{c}-0.008284 \\
(0.000)\end{array}$ & $\begin{array}{c}-0.002214 \\
(0.466)\end{array}$ & $\begin{array}{c}-\mathbf{0 . 0 3 7 7} \\
(\mathbf{0 . 0 0 0 )})\end{array}$ & $\begin{array}{c}-0.004769 \\
(0.052)\end{array}$ \\
\hline Indirect effect & $\begin{array}{c}-0.000614 \\
(0.846)\end{array}$ & $\begin{array}{c}0.003706 \\
(0.272)\end{array}$ & $\begin{array}{c}-0.000424 \\
(0.322)\end{array}$ & $\begin{array}{c}-0.000108 \\
(0.846)\end{array}$ & $\begin{array}{c}-0.00039 \\
(0.854)\end{array}$ & $\begin{array}{c}-0.000654 \\
(0.182)\end{array}$ \\
\hline Total effect & $\begin{array}{c}-0.001728 \\
(0.845)\end{array}$ & $\begin{array}{c}0.017768 \\
(0.014)\end{array}$ & $\begin{array}{c}-0.008708 \\
(0.000)\end{array}$ & $\begin{array}{c}-0.002323 \\
(0.446)\end{array}$ & $\begin{array}{c}-0.03809 \\
(0.000)\end{array}$ & $\begin{array}{c}-0.005423 \\
(0.055)\end{array}$ \\
\hline Wald chi2 test & $\begin{array}{c}7.44 \\
(0.0242)\end{array}$ & $\begin{array}{c}10.97 \\
(0.0041)\end{array}$ & $\begin{array}{c}17.39 \\
(0.0002)\end{array}$ & $\begin{array}{c}0.73 \\
(0.6927)\end{array}$ & $\begin{array}{c}107.86 \\
(0.0000)\end{array}$ & $\begin{array}{c}8.08 \\
(0.0176)\end{array}$ \\
\hline Pseudo $\mathbf{R}^{2}$ & 0.0563 & 0.3368 & 0.5124 & 0.0495 & 0.8709 & 0.2343 \\
\hline $\begin{array}{l}\text { Moran test for spatial } \\
\text { dependence }\end{array}$ & $\begin{array}{c}5.86 \\
(0.0155)\end{array}$ & $\begin{array}{c}1.61 \\
(0.2042)\end{array}$ & $\begin{array}{c}0.58 \\
(0.4465)\end{array}$ & $\begin{array}{c}0.03 \\
(0.8714)\end{array}$ & $\begin{array}{c}0.00 \\
(0.9532)\end{array}$ & $\begin{array}{c}7.57 \\
(0.0060)\end{array}$ \\
\hline Wald test of spatial terms & $\begin{array}{c}7.44 \\
(0.0064)\end{array}$ & $\begin{array}{c}1.64 \\
(0.2009)\end{array}$ & $\begin{array}{c}1.21 \\
(0.2718)\end{array}$ & $\begin{array}{c}0.04 \\
(0.8482)\end{array}$ & $\begin{array}{c}0.03 \\
(0.8534)\end{array}$ & $\begin{array}{c}4.61 \\
(0.0317)\end{array}$ \\
\hline \multicolumn{7}{|c|}{ Generalized spatial two-stage least squares (GS2SLS) estimation } \\
\hline & $\begin{array}{c}1891- \\
1913\end{array}$ & $\begin{array}{c}1913- \\
1945\end{array}$ & $\begin{array}{l}1946- \\
1994\end{array}$ & $\begin{array}{c}1995- \\
2016\end{array}$ & $\begin{array}{c}1959- \\
1969\end{array}$ & $\begin{array}{l}1891- \\
2009\end{array}$ \\
\hline$\alpha($ constant $)$ & $\begin{array}{c}0.015812 \\
(0.712)\end{array}$ & $\begin{array}{c}-0.115508 \\
(0.025)\end{array}$ & $\begin{array}{c}0.104732 \\
(0.000)\end{array}$ & $\begin{array}{c}0.031735 \\
(0.360)\end{array}$ & $\begin{array}{c}0.385725 \\
(0.000)\end{array}$ & $\begin{array}{c}0.053604 \\
(0.005)\end{array}$ \\
\hline$\beta$ (initial per capita GDP level) & $\begin{array}{l}-0.000745 \\
(0.892)\end{array}$ & $\begin{array}{l}0.013082 \\
(0.035)\end{array}$ & $\begin{array}{c}-0.008278 \\
(0.000)\end{array}$ & $\begin{array}{c}-0.002963 \\
(0.384)\end{array}$ & $\begin{array}{c}-0.037629 \\
(0.000)\end{array}$ & $\begin{array}{c}-0.004742 \\
(0.052)\end{array}$ \\
\hline $\begin{array}{l}\rho \text { (spatial autoregressive } \\
\text { parameter) }\end{array}$ & $\begin{array}{l}0.325119 \\
(0.087)\end{array}$ & $\begin{array}{l}0.303661 \\
(0.155)\end{array}$ & $\begin{array}{l}0.056331 \\
(0.274)\end{array}$ & $\begin{array}{c}-0.160209 \\
(0.749)\end{array}$ & $\begin{array}{l}0.017929 \\
(0.780)\end{array}$ & $\begin{array}{c}0.138642 \\
(0.037)\end{array}$ \\
\hline Direct effect & $\begin{array}{c}-0.000768 \\
(0.892)\end{array}$ & $\begin{array}{c}\mathbf{0 . 0 1 3 4 3 3} \\
(\mathbf{0 . 0 2 9})\end{array}$ & $\begin{array}{c}-0.008284 \\
(0.000)\end{array}$ & $\begin{array}{c}-0.002981 \\
(0.393)\end{array}$ & $\begin{array}{c}-0.037632 \\
(0.000)\end{array}$ & $\begin{array}{c}-0.004766 \\
(0.052)\end{array}$ \\
\hline Indirect effect & $\begin{array}{c}-0.000291 \\
(0.894)\end{array}$ & $\begin{array}{c}0.004642 \\
(0.250)\end{array}$ & $\begin{array}{c}-0.000426 \\
(0.325)\end{array}$ & $\begin{array}{c}0.000376 \\
(0.781)\end{array}$ & $\begin{array}{c}-0.000598 \\
(0.782)\end{array}$ & $\begin{array}{c}-0.000644 \\
(0.188)\end{array}$ \\
\hline Total effect & $\begin{array}{c}-0.001059 \\
(0.892)\end{array}$ & $\begin{array}{c}0.018074 \\
(0.020)\end{array}$ & $\begin{array}{c}-0.00871 \\
(0.000)\end{array}$ & $\begin{array}{c}-0.002605 \\
(0.322)\end{array}$ & $\begin{array}{c}-0.03823 \\
(0.000)\end{array}$ & $\begin{array}{c}-0.00541 \\
(0.055)\end{array}$ \\
\hline Wald chi2 test & $\begin{array}{c}2.94 \\
(0.2305)\end{array}$ & $\begin{array}{c}11.39 \\
(0.0034)\end{array}$ & $\begin{array}{c}17.38 \\
(0.0002)\end{array}$ & $\begin{array}{c}0.78 \\
(0.6773)\end{array}$ & $\begin{array}{c}107.85 \\
(0.0000)\end{array}$ & $\begin{array}{c}7.83 \\
(0.0199)\end{array}$ \\
\hline Pseudo $\mathbf{R}^{2}$ & 0.0579 & 0.3187 & 0.5124 & 0.0229 & 0.8708 & 0.2346 \\
\hline $\begin{array}{l}\text { Moran test for spatial } \\
\text { dependence }\end{array}$ & $\begin{array}{c}5.86 \\
(0.0155)\end{array}$ & $\begin{array}{c}1.61 \\
(0.2042)\end{array}$ & $\begin{array}{c}0.58 \\
(0.4465)\end{array}$ & $\begin{array}{c}0.03 \\
(0.8714)\end{array}$ & $\begin{array}{c}0.00 \\
(0.9532)\end{array}$ & $\begin{array}{c}7.57 \\
(0.0060)\end{array}$ \\
\hline Wald test of spatial terms & $\begin{array}{c}2.93 \\
(0.0868)\end{array}$ & $\begin{array}{c}2.02 \\
(0.1550)\end{array}$ & $\begin{array}{c}1.20 \\
(0.2742)\end{array}$ & $\begin{array}{c}0.10 \\
(0.7493)\end{array}$ & $\begin{array}{c}0.08 \\
(0.7804)\end{array}$ & $\begin{array}{c}4.37 \\
(0.0366)\end{array}$ \\
\hline
\end{tabular}

Source: Own calculations in Stata 15 (StataCorp, 2017); p-values in parenthesis 
Moran tests for spatial dependence indicate that the errors are independent and identically distributed (i.i.d.) for the periods 1913-1945, 1946-1994, 1959-1969 and 1995-2016. Similar results were produced by the Wald test of spatial terms. There is no significant spatial dependence across nearby regions. This is the reason why the indirect effects are insignificant. Despite the significance of the both spatial tests for the periods 1891-1913 and 1891-2009, the indirect effects are insignificant as well. Thus, the spatial spillovers are assumed to be negligible for any observed period. It implies that the average growth rate of per capita GDP in a given region is not significantly influenced by those of neighboring regions (Le Gallo, Ertur and Baumon 2003). This conclusion suggests that the original model of absolute Beta-convergence estimated through OLS does not suffer from a misspecification caused by omitted spatial dependence (Rey and Montouri 1999).

The direct (own-region) effect is significant for four periods (1913-1945, 1946-1994, 1959-1969 and 1891-2009) for both methods (ML and GS2SLS). Compared to OLS, the span 1891-2009 is now significant. The positive and significant direct effect for the period 19131945 implies divergence and the negative and significant direct effect for the periods 19461994, 1959-1969 and 1891-2009 implies the presence of Beta-convergence. Wald tests for these four periods are significant as well. Pseudo $\mathrm{R}^{2}$ (similar for both methods of estimation) varies from 0.23 (1891-2009) to 0.87 (1959-1969). The insignificant direct effect for 18911913 and 1995-2016 indicates no confirmation of Beta-convergence or divergence. These periods are characterized by insignificant Wald tests and very low pseudo $\mathrm{R}^{2}$.

We used the estimated $\beta$ coefficients (OLS) and the direct effects (ML and GS2SLS) to compute the speed of convergence and the half-life for each period. The results are displayed in Table 3. Stated significance level is the significance level of the related estimated coefficients used for the computation ( $\beta$ coefficients or the direct effects).

Table 3: Summary of results of different cross-sectional models of Beta-convergence across 16 Italian regions (1891-2016)

\begin{tabular}{|c|c|c|c|c|c|c|}
\hline & 1891-1913 & 1913-1945 & 1946-1994 & 1995-2016 & 1959-1969 & 1891-2009 \\
\hline \multicolumn{7}{|c|}{ Absolute Beta-convergence (OLS) } \\
\hline Conclusion & uncertain & divergence $* *$ & convergence $* * *$ & uncertain & convergence $* * *$ & uncertain \\
\hline $\begin{array}{l}\text { Speed of } \\
\text { convergence }\end{array}$ & $-0.029 \%$ & $-1.356 \%$ & $1.009 \%$ & $0.246 \%$ & $4.753 \%$ & $0.649 \%$ \\
\hline Half-life & - & - & 68.71 & 281.35 & 14.58 & 106.76 \\
\hline \multicolumn{7}{|c|}{ Spatial lag model (ML) } \\
\hline Conclusion & uncertain & divergence $^{* *}$ & convergence $* * *$ & uncertain & convergence $* * *$ & convergence* \\
\hline $\begin{array}{l}\text { Speed of } \\
\text { convergence }\end{array}$ & $0.113 \%$ & $-1.161 \%$ & $1.056 \%$ & $0.227 \%$ & $4.732 \%$ & $0.701 \%$ \\
\hline Half-life & 614.5 & - & 65.64 & 305.71 & 14.65 & 98.86 \\
\hline \multicolumn{7}{|c|}{ Spatial lag model (GS2SLS) } \\
\hline Conclusion & uncertain & divergence $* *$ & convergence $^{* * *}$ & uncertain & convergence $* * * *$ & convergence* \\
\hline $\begin{array}{l}\text { Speed of } \\
\text { convergence }\end{array}$ & $0.077 \%$ & $-1.117 \%$ & $1.056 \%$ & $0.308 \%$ & $4.721 \%$ & $0.700 \%$ \\
\hline Half-life & 894.65 & - & 65.64 & 225.17 & 14.68 & 98.97 \\
\hline
\end{tabular}

Source: Own calculations 
There are two most considerable periods in terms of Beta-convergence across Italian regions according to the results reported in Table 3. The first one is the divergence era (1913-1945) which started on the eve of WWI and continued through the fascist interwar period until the end of WWII. The speed of convergence (annual rate of convergence) during this era was about $-1.2 \%$ (average of the three methods of estimation). The second one is the convergence era (1959-1969) during the post-war economic boom miracolo economico italiano with the speed of convergence about $4.7 \%$ and the half-life about 14.6 years. The period 1946-1994 including years 1959-1969 was period of Beta-convergence as a whole, however the speed of convergence for the whole period was lower (about $1 \%$ ) with the half-life about 66.7 years. The strong Beta-convergence during the 1950s and 1960s was replaced by stagnation of convergence since the 1970s (see Daniele and Malanima 2011). The period 1891-2009 offers less convincing evidence of Beta-convergence. There is no significant result for this period when the spatial spillovers are not included. The spatial lag model assumes the presence of Beta-convergence which is characterized by the speed of convergence $0.7 \%$ and the half-life about 98.9 years. The periods 1891-1913 and 1995-2016 do not reveal the presence of significant Beta-convergence or divergence.

\section{Conclusion}

Investigation of Beta-convergence across regions was very popular in the 1990s when Barro and Sala-i-Martin published their works related to this topic. Meanwhile the spatial econometrics methods have undergone considerable progress. This progress is evidenced by the fitting name of the paper publish by Arbia (2016) - Spatial Econometrics: A Rapidly Evolving Discipline. The spatial econometrics methods used for Beta-convergence analysis became very popular in the recent years. In this paper we have applied these methods.

Our investigation was based on the spatial econometric analysis of Beta-convergence across Italian regions in the long term using real per capita GDP. The problem of regional data limitations was solved by using the reconstructed historical dataset for the period 1891-2009. Moreover, we have used regional data from ISTAT for the period 1995-2016. The whole time span 1891-2016 was divided into shorter ones according to the political setup and important milestones in the Italian history. We have estimated two types of cross-sectional model: absolute Beta-convergence model and the spatial lag model. The first one was estimated by OLS and the second one by ML and GS2SLS.

There are two most remarkable periods in terms of Beta-convergence across Italian regions: 1913-1945 and 1959-1969. The first one is the divergence era with the speed of convergence about $-1.2 \%$. This period started on the eve of WWI and continued through the fascist interwar period until the end of WWII. The period 1959-1969 was identified during our econometric analysis as the most considerable in terms of Beta-convergence with the speed of convergence about $4.7 \%$ and the half-life about 14.6 years. This fast convergence took place during the postwar miracolo economico italiano. The period 1946-1994 including years 1959-1969 was the period of Beta-convergence as a whole, however the speed of convergence for the whole period was low (1\%). The spatial lag model for the period 1891-2009 offers less convincing evidence of the Beta-convergence with the speed of convergence $0.7 \%$. The analysis of the periods 1891-1913 and 1995-2016 does not reveal the presence of significant Beta-convergence or divergence. We have identified that the original model of absolute Beta-convergence estimated through OLS does not suffer from a misspecification caused by omitted spatial dependence. Spatial spillovers are assumed to be negligible due to insignificant indirect effects. 
Finally, after the evaluation of the long-term convergence process across Italian regions in the period 1891-2016, we conclude that the stagnation of convergence is not unusual. Moreover, in the Italian modern history there was also the period of divergence. However, reduction of the North-South divide will be a serious challenge for the current and future Italian governments.

\section{Acknowledgement}

I would like to express my deep gratitude to Professor Paolo Malanima, Università degli Studi "Magna Graecia" di Catanzaro (Italy) for his help in providing me the database of reconstructed historical data in electronic form.

This paper was financially supported within the VŠB - Technical University SGS grant project No. SP2018/138 (Implications for Fiscal and Monetary Policy of Advanced Countries: An Econometric Approach).

\section{References}

[1] ABREU, M., H. L. F. DE GROOT and R. J. G. M. FLORAX, 2005. Space and Growth: A Survey of Empirical Evidence and Methods. Région et Développement, No. 21, pp. 13-44. ISSN 1267-5059.

[2] ANSELIN, L. and A. K. BERA, 1998. Spatial Dependence in Linear Regression Models with an Introduction to Spatial Econometrics. In: A. ULLAH and D. E. A. GELIS, eds. Handbook of Applied Economic Statistics. New York: Marcel Dekker, pp. 237-289. ISBN 978-0-8247-0129-1.

[3] ANSELIN, L., 2001. Spatial Econometrics. In: B. H. BALTAGI, ed. A Companion to Theoretical Econometrics. Malden, Mass.: Blackwell Publishing. ISBN 978-0-631-212546.

[4] ANSELIN, L., J. LE GALLO and H. JAYET, 2008. Spatial Panel Econometrics. In: L. MÁTYÁS and P. SEVESTRE, eds. The Econometrics of Panel Data, Fundamentals and Recent Developments in Theory and Practice, 3rd ed. Berlin, Heidelberg: Springer-Verlag, pp. 625-660. ISNB 978-3-540-75889-1.

[5] ARBIA, G. and B. H. BALTAGI, 2010. Spatial Econometrics. Methods and Applications. Heidelberg: Physica-Verlag. ISBN 978-3-7908-2563-3.

[6] ARBIA, G. and R. BASILE, 2005. Spatial Dependence and Non-Linearities in Regional Growth Behaviour in Italy. Statistica, Vol. 65, No. 2, pp. 145-167. ISSN 1973-2201.

[7] ARBIA, G., 2014. A Primer for Spatial Econometrics: With Applications in R. New York: Palgrave Macmillan. ISBN 978-0-230-36038-9.

[8] ARBIA, G., 2016. Spatial Econometrics: A Rapidly Evolving Discipline. Econometrics, Vol. 4, No. 1. ISSN 2225-1146.

[9] ARBIA, G., R. BASILE and G. PIRAS, 2005. Using Spatial Panel Data in Modelling Regional Growth and Convergence. ISAE Working Paper, No. 55. Roma: L'Istituto di Studi e Analisi Economica (ISAE).

[10] BARRO, R. J. and X. SALA-I-MARTIN, 1990. Economic Growth and Convergence across The United States. NBER Working Paper Series, No. 3419. ISSN 0898-2937.

[11] BARRO, R. J. and X. SALA-I-MARTIN, 1992. Convergence. The Journal of Political Economy, Vol. 100, No. 2, pp. 223-251. ISSN 0022-3808. 
[12] BARRO, R. J. and X. SALA-I-MARTIN, 2004. Economic growth. 2nd ed. Cambridge, Mass.: MIT Press. ISBN 0-262-02553-1.

[13] BELARDI, J., 2018. Spending on Public Pensions in the Context of Political System: Evidence from Italian First Republic. In: L. Filipová et al., eds. Proceedings of 15th International Conference Economic Policy in the European Union Member Countries. Ostrava: VŠB-TU Ostrava, pp. 26-42. ISBN 978-80-248-4155-7.

[14] DANIELE, V. and P. MALANIMA, 2011. Il divario Nord-Sud in Italia, 1861-2011. Soveria Mannelli: Rubbettino. ISBN 9788849831290.

[15] ELHORST, J. P., 2014. Spatial Econometrics: From Cross-Sectional Data to Spatial Panels. Berlin, Heidelberg: Springer-Verlag. ISBN 978-3-642-40339-2.

[16] EUROPEAN COMMISSION, 2017. Seventh Report on Economic, Social and Territorial Cohesion - My region, My Europe, Our Future [online]. Luxembourg: Publications Office of the European Union [cit. 15th July 2018]. ISBN 978-92-79-71834-2. Accessible from: http://ec.europa.eu/regional_policy/sources/docoffic/official/reports/cohesion7/7cr.pdf.

[17] IAMMARINO, S., A. RODRÍGUEZ-POSE and M. STORPER, 2017. Why Regional Development Matters for Europe's Economic Future [online]. Working Paper, No. 07/2017 (Directorate General for Regional and Urban Policy, European Commission). Luxembourg: Publications Office of the European Union [cit. 15th July 2018]. Accessible from:

http://ec.europa.eu/regional_policy/sources/docgener/work/201707_regional_developme nt_matters.pdf.

[18] ISTAT [Istituto Nazionale di Statistica], 2011. Confini amministrativi di regioni, province e comuni al $1^{\circ}$ gennaio 2011 - shapefile poligonale "reg2011" [online]. [cit. 7th July 2018]. Accessible from: http://www.istat.it/it/files/2011/04/reg2011.zip.

[19] ISTAT [Istituto Nazionale di Statistica], 2018a. Conti nazionali (Conti e aggregati economici territoriali) [online]. [cit. 7th July 2018]. Accessible from: http://dati.istat.it/.

[20] ISTAT [Istituto Nazionale di Statistica], 2018b. Popolazione e famiglie (Popolazione residente - bilancio; Popolazione Intercensuaria) [online]. [cit. 7th July 2018]. Accessible from: http://dati.istat.it/.

[21] KELEJIAN, H. H. and I. R. PRUCHA, 1998. A Generalized Spatial Two-Stage Least Squares Procedure for Estimating a Spatial Autoregressive Model with Autoregressive Disturbances. Journal of Real Estate Finance and Economics, Vol. 17, No. 1, pp. 99-121. ISSN 0895-5638.

[22] LE GALLO, J., C. ERTUR and C. BAUMONT, 2003. A Spatial Econometric Analysis of Convergence Across European Regions, 1980-1995. In: B. Fingleton, ed. European Regional Growth. Berlin, Heidelberg: Springer-Verlag, pp. 99-129. ISBN 978-3-64205571-3.

[23] LESAGE, J. and R. K. PACE, 2009. Introduction to Spatial Econometrics. Boca Raton, FL: Chapman \& Hall/CRC. ISBN 978-1-4200-6424-7.

[24] LESAGE, J., 2014. What Regional Scientists Need to Know about Spatial Econometrics. The Review of Regional Studies, Vol. 44, No. 1, pp. 13-32. ISSN 0048-749X.

[25] PIRAS, G. and G. ARBIA, 2007. Convergence in per-capita GDP across EU-NUTS2 Regions using Panel Data Models Extended to Spatial Autocorrelations Effects. Statistica, Vol. 67, No. 2, pp. 157-172. ISSN 1973-2201. 
[26] QGIS DEVELOPMENT TEAM, 2018. QGIS 3.2 Bonn Geographic Information System. Beaverton, OR.: Open Source Geospatial Foundation. Accessible from: https://www.qgis.org/.

[27] QUAH, D. T., 1995. Regional Convergence Clusters across Europe [online]. Centre for Economic Performance Discussion Paper, No. 274. [cit. 25th July 2018]. Accessible from: http://cep.lse.ac.uk/pubs/download/DP0274.pdf.

[28] REY, S. J. and B. D. MONTOURI, 1999. US Regional Income Convergence: A Spatial Econometric Perspective. Regional Studies, Vol. 33, No. 2, pp. 143-156. ISSN 0034-3404.

[29] SALA-I-MARTIN, X., 1996. The Classical Approach to Convergence Analysis. The Economic Journal, Vol. 106, No. 437, 1996. pp. 1019-1036. ISSN 0013-0133.

[30] SOLOW, R. M., 1956. A Contribution to the Theory of Economic Growth. The Quarterly Journal of Economics, Vol. 70, No. 1, pp. 65-94.

[31] STATACORP, 2017. Stata: Release 15. Statistical Software. College Station, TX: StataCorp LLC.

[32] SWAN, T. W., 1956. Economic Growth and Capital Accumulation. Economic Record, Vol. 32, No. 2, pp. 334-361. 


\section{Appendix}

Administrative structure of Italy (official and aggregate version)
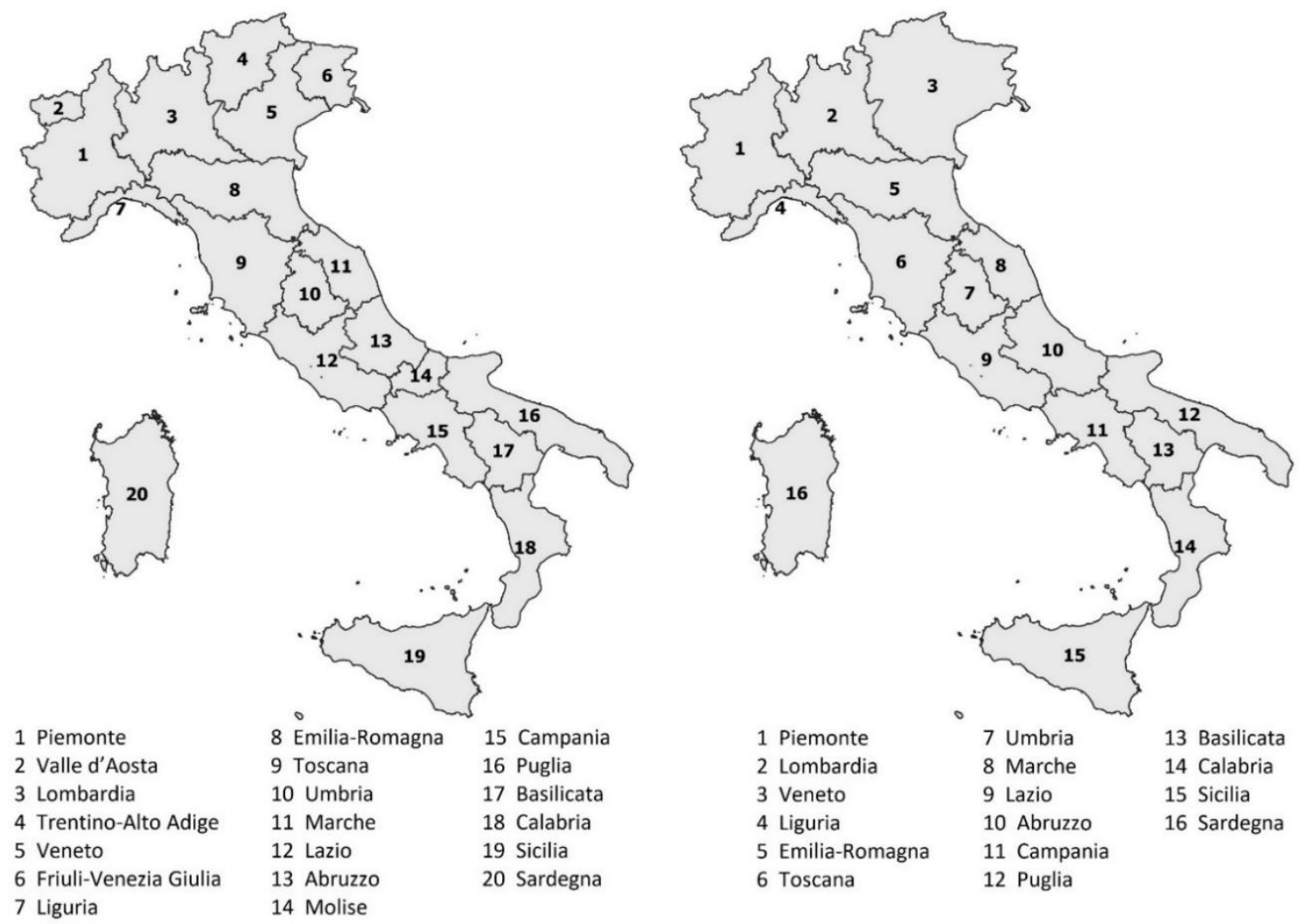

Source: Own elaboration in QGIS 3.2 Bonn Geographic Information System (QGIS Development Team, 2018) based on shapefile from ISTAT (2011) 